Journal Ability : : Journal of Education and Social Analysis

Volume 2, Issue 3, Juli 2021

\title{
Prinsip Dan Proses Pembuatan Keputusan
}

\section{Isra Adawiyah Siregar}

Universitas Islam Negeri Sumatera Utara Medan

Corresponding Author : izraadawiyah@gmail.com

\begin{tabular}{ll}
\hline \multicolumn{1}{c}{ ABSTRACT } \\
\cline { 2 - 2 } & $\begin{array}{l}\text { Penelitian ini bertujuan untuk mengetahui prinsip dan proses pembuatan } \\
\text { keputusan. Hasil penelitian ini menunjukkan bahwa Pembuatan } \\
\text { keputusan mengenal berbagai prinsip dasar sehingga baik dalam tahapan } \\
\text { perumusan maupun implementasinya pembuatan keputusan tersebut } \\
\text { memenuhi syarat sebagai alat manajemen yang dapat memberikan } \\
\text { panduan bagi anggota dalam bertindak dan berprilaku. Adapun Prinsip- } \\
\text { Prinsip tersebut antara lain : Keputusan pada dasarnya ditujukan untuk } \\
\text { memecahkan masalah, karena itu setiap alternatif solusi hendaknya tepat } \\
\text { untuk masalah yang dituju, setiap keputusan hendaknya merupakan } \\
\text { alternatif terbaik dengan resiko yang amat minial, keputusan hendaknya } \\
\text { sudah mempertimbangkan lingkup dan resiko secara sistematik dan } \\
\text { sistemik, keputusan hendaknya tidak berada diluar zona of acceptance } \\
\text { manusia, keputusan yang efektif adalah keputusan yang dapat } \\
\text { dilaksanakan, keputusan hendaknya memecahkan masalah yang generik } \\
\text { bukan masalah yang oprasional teknis, kembuatan Keputusan terdiri dari } \\
\text { tahap perumusan keputusan dan implementasi keputusan, pembuatan } \\
\text { keputusan hendaknya menghasilkan suatu hasil yang dapat diukur serta } \\
\text { keputusan tidak selalu harus dimulai dari data, tapi dari judgement. }\end{array}$ \\
\cline { 2 - 3 } Kata Kunci & $\begin{array}{l}\text { Prinsip, Proses, Keputusan } \\
\text { How to cite }\end{array}$ \\
\cline { 2 - 3 } & (2021). Jurnal Ability, 2(3). \\
\hline
\end{tabular}

\section{PENDAHULUAN}

Pembuatan keputusan merupakan salah satu unsur yang sangat esensial dalam organisasi dan manajemen. Pembuatan keputusan bukan hanya fungsi pimpinan, tapi juga suatu proses partisipasi seluruh anggota untuk meningkatkan fungsi-fungsi manajemen. Bagi pimpinan pembuatan keputusan itu merupakan salah satu fungsi untuk yang tidak dapat dihindari untuk tidak melakukannya, sebab tanpa pembuatan keputusan fungsi kepemimpinan tidak dapat dilaksanakan dan pungsi manajemen tidak dapat berjalan untuk mewujudkan tujuan organisasi.

Simon dalam Muhammad Rifa'I (2020: 6) mengemukakan bahwa keputusan itu adalah suatu manifestasi kewenangan pimpinan yang sangat diharapkan oleh bawahan, sebab tanpa pembuatan keputusan, seluruh 
Ability : Journal of Education and Social Analysis

Volume 2, Issue 3, Juli 2021

Page : 41-51

kegiatan bawahan menjadi tidak pasti. Ketidak pastian ini menyebabkan lemahnya pimpinan yang dapat mengakibatkan labilnya organisasi. Kelabilan ini merupakan titik awal kehancuran organisasi. Dalam bidang pendidikan, penyelenggaraan pendidikan hanya mungkin dilaksanakan bila didasarkan atas kebijakan dan perencanaan yang menyeluruh dan mantap untuk menghadapi masa depan. Kebijakan dan perencanaan pengembangan pendidikan ini adalah bentuk seperangkat keputusan-keputusan untuk mengendalikan dan merekayasa masa depan dalam upaya membangun manusia Indonesia untuk menghadapi masa depan. Pembuatan keputusan dengan demikian dalam pembangunan pendidikan memegang peran strategis dan karenanya kualitas pembuatan keputusan merupakan titik sentral dalam proses pembuatan keputusan. Ini mengandung arti bahwa untuk menghasilkan keputusan yang bermutu, keputusan itu menuntut dipenuhinya persyaratan professional yang harus di miliki oleh setiap pemimpin atau manager yang professional.

\section{METODOLOGI PENELITIAN}

Penelitian ini menggunakan studi kepustakaan (library research). Dalam memperoleh data penelitian, peneliti mengumpulkan, menganalisis, mengorganisasi, sumber dari artikel, buku, penelitian terdahulu tentang implementasi manajemen strategi dalam bidang pendidikan. Kemudian peneliti menyimpulkan dan menyajikan data-data manajemen strategi untuk peningkatan mutu pendidikan (Danandjaja, 2014; Sari \& Asmendri, 2020; Zed, 2014).

\section{HASIL PENELITIAN DAN PEMBAHASAN}

\section{A. Prinsip dan Proses Pembuatan keputusan}

\section{Prinsip Pembuatan Keputusan}

Pembuatan keputusan atau decision making adalah proses memilih atau menentukan berbagai kemungkinan-kemungkinan diantara situasi-situasi yang tidak pasti. Suharman (2005:194) berpendapat bahwa pembuatan keputusan terjadi didalam situasi yang meminta seseorang harus a) membuat prediksi kedepan, b) memilih salah satu diantara dua pilihan atau lebih atau membuat estimasi (perkiraan) mengenai frekuensi kejadian berdasarkan bukti-bukti yang terbatas. Ketika dihadapkan dengan dua pilihan, maka dalam pengambilan keputusan diantara satu pilihan harus diprediksi terlebih dahulu agar tidak terjadi resiko yang besar terhadap keputusan yang sudah ditentukan. 
Page : 41-51

Pembuatan keputusan mengenal berbagai prinsip dasar sehingga baik dalam tahapan perumusan maupun implementasinya pembuatan keputusan tersebut memenuhi syarat sebagai alat manajemen yang dapat memberikan panduan bagi anggota dalam bertindak dan berprilaku. Adapun PrinsipPrinsip tersebut menurut Muhdi (2017: 78) adalah sebagai berikut:

1) Keputusan pada dasarnya ditujukan untuk memecahkan masalah, karena itu setiap alternatif solusi hendaknya tepat untuk masalah yang dituju.

2) Setiap keputusan hendaknya merupakan alternatif terbaik dengan resiko yang amat minial.

3) Keputusan hendaknya sudah mempertimbangkan lingkup dan resiko secara sistematik dan sistemik.

4) Keputusan hendaknya tidak berada diluar zona of acceptance manusia.

5) Keputusan yang efektif adalah keputusan yang dapat dilaksanakan.

6) Keputusan hendaknya memecahkan masalah yang generik bukan masalah yang oprasional teknis.

7) Pembuatan Keputusan terdiri dari tahap perumusan keputusan dan implementasi keputusan.

8) Pembuatan keputusan hendaknya menghasilkan suatu hasil yang dapat diukur.

9) Keputusan tidak selalu harus dimulai dari data, tapi dari judgement.

Mann dalam Mustiningsih (2014: 14) menyatakan bahwa pembuatan keputusan harus rational dan reasonable. Lebih lengkap, prinsip pembuatan keputusan dikemukakan oleh Robbins yang membedakan prinsip pembuatan keputusan individual dan kelompok. Prinsip pembuatan Individual meliputi:

1) Analisislah situasi

2) Menyadari adanya bias

3) Kombinasikan model rasional dan intuisi

4) Jangan berasumsi bahwa pembuatan keputusan cocok untuk semua pekerjaan

5) Tingkatkan kreatifitas

Pembuatan keputusan kelompok harus memperhatikan efektifitas kelompok yang terdiri atas:

1) Jumlah ide

2) Kualitas ide

3) Tekanan sosial

4) Biaya

5) Kecepatan 
Ability : Journal of Education and Social Analysis

Volume 2, Issue 3, Juli 2021

Page : 41-51

6) Orientasi tugas

7) Potensi terjadinya konflik antar pribadi

8) Perasaan pada prestasi

9) Komitmen penyelesaian

10) Pengembangan kelompok kohesif

Keseluruhan prinsip di atas dapat dijadikan dasar dalam setiap pembuatan keputusan. Dengan menerapkan prinsip tersebut pembuat keputusan dapat terhindar dari berbagai kesalahan dalam menggunakan pembuatan keputusan. Ini mengandung arti bahwa kekacauan manajemen yang acap kali disebabkan oleh pembuatan keputusan yang tidak didasarkan kepada prinsip yang tepat dapat dihindari.

\section{Proses Pembuatan Keputusan}

Siagian (1986) mengungkapkan delapan langkah pengambilan keputusan, yaitu: (1) definisi masalah, (2) pengumpulan data, (3) analisis data, (4) penentuan alternatif, (5) pemilihan alternatif yang terbaik, (6) putuskan, (7) implementasikan dan monitor hasil, dan (8) evaluasi. Sebelum menetapkan suatu keputusan, hendaknya pembuat keputusan harus memahami terlebih dahulu titik permasalahan yang tengah di hadapi oleh organisasi dan mulai mengumpulkan data-data yang dapat menjawab permasalahan yang tengah dihadapi serta dianalisis dengan cermat untuk meminimalisir terjadinya kegagalan dalam pengambilan keputusan. Selanjutnya adalah dengan menentukan alternatif dari keputusan yang akan dibuat dan sebaiknya pemilihan alternatif dilakukan dengan memperhatikan masalah yang tengah dihadapi. Setelah ditetapkannya keputusan, lalu implementasikan dan lihat bagaimana efek yang terjadi ketika keputusan itu sudah dilaksanakan. Dan kegiatan terakhir adalah evaluasi, kegiatan ini merupakan hal sangat penting untuk dilakukan dalam kegiatan pengambilan keputusan. Kegiatan ini meninjau kembali apakah dampak yang terjadi setelah keputusan itu diambil. Jika memberikan dampak yang negatif maka disinilah alternatif itu dimanfaatkan.

Disisi lain Imansyah (2017: 57) mengemukakan proses pembuatan keputusan terdiri dari dua tahapan yaitu: tahapan perumusan keputusan dan tahapan implementasi keputusan. Setiap tahapan terdiri dari berbagai langkah atau kegiatan yang secara sistematik dan runtun perlu diikuti oleh setiap pembuat keputusan. Keseluruhan rincian tahapan dan kegiatan pembuatan keputusan tersebut tercantum di bawah ini.

a) Perumusan Keputusan

1) Identifikasi masalah 
Keputusan diperlukan untuk memecahkan masalah-masalah. Langkah pertama yang harus dilakukan oleh pembuat keputusan adalah masalah-masalah apa saja yang harus diputuskan. Menurut Peter Drucker, seorang eksekutif yang efektif tidak membuat keputusan untuk setiap masalah. Masalah yang harus mendapat perhatian adalah masalah-masalah mendasar yang mempunyai dampak luas dan menyeluruh bagi anggota dan bagi organisasi. Masalah-masalah ini disebut dengan "generic problems". Masalah biasa tidak perlu diputuskan oleh eksekutif, tapi cukup oleh pimpinan tingkat yang lebih rendah berdasarkan aturan organisasi yang berlaku. Identifikasi masalah generik ini tidak perlu ditunjang oleh data yang lengkap, sebab bila data yang lengkap harus terkumpul dahulu, maka tidak akan ada suatu keputusan. Keputusan dapat dimulai dari judgment rasional dari seorang pemimpin.

2) Perumusan tujuan

Tujuan apakah yang harus dicapai melalui pemecahan suatu masalah? Asumsi dasar untuk setiap keputusan adalah bahwa suatu keputusan dibuat oleh seorang pemimpin untuk mencapai tujuan tertentu. Ini berarti tidak hanya masalah yang dipecahkan saja yang perlu jelas, tapi juga tujuan yang akan dicapainya harus labih jelas lagi. Kejelasan tujuan ini diperlukan sebagai pedoman untuk menentukan pilihan-pilihan keputusan yang paling tepat untuk suatu masalah. Keberhasilan suatu keputusan ditentukan oleh "apakah tujuan yang sudah ditetapkan itu akhirnya dapat dicapai atau tidak". Tujuan untuk masalah-masalah yang generik harus dirumuskan secara umum dan mendasar, yang kemudian diterjemahkan kedalam tujuan-tujuan yang lebih operasional yang disebut dengan objektif. Setiap objektif perlu pula dijabarkan kedalam target-target baik yang bersifat kuantitatif maupun kualitatif. Suatu "decision tree" perlu dikembangkan sehingga jangkauan dampak dan lingkup suatu keputusan dapat diketahui dengan jelas.

3. Identifikasi Alternatif Solusi

Alternatif solusi atau pemecahan untuk suatu masalah sangat penting karena setiap masalah tidak mungkin dipecahkan hanya oleh suatu cara pemecahan saja. Alternatif-alternatif ini diperlukan untuk sampai kepada pilihan keputusan yang tepat dengan resiko yang sangat minimal. Identifikasi alternatif solusi ini ditentukan oleh: latar belakang pendidikan, pengalaman hidup, tingkat kecerdasan, kemampuan antisipatif, kemampuan berfikir kedepan, imaginasi, cita-cita, kreativitas, 
Page : 41-51

dan kemampuan untuk melihat secara jeli setiap resiko dan dampak serta peluang yang mungkin diciptakan oleh suatu alternatif keputusan tertentu.

4. Penentuan Kriteria Pemilihan Alternatif Solusi

Kriteria suatu alternatif pemecahan sangat sulit dikembangkan secara pasti, karena sangat bergantung kepada kondisi dan visi pembuat dan pelaksana keputusan untuk mencapai tujuan yang telah ditentukan. Namun demikian kriteria umum dapat diungkap seperti dibawah ini:

a. Alternatif solusi itu harus tepat untuk mencapai tujuan yang telah ditentukan

b. Altertnatif solusi itu harus jelas dampak, resiko dan peluang yang mungkin diciptakan

c. Alternatif solusi itu harus feasible untuk dilaksanakan

d. Alternatif solusi itu harus tidak bertentangan dengan nilai, etika, moral yang dipegang oleh anggota organisasi dan oleh organisasi.

e. Alternatif solusi itu harus membawa perubahan bagi organisasi menuju yang lebih baik dari keadaan sekarang.

Secara operasional akhirnya kriteria ini sangat ditentukan oleh pembuat keputusan. Alternatif solusi yang dipilih mungkin mempunyai resiko tinggi dan sulit dilaksanakan, tapi dapat membawa perubahan yang diinginkan. Dalam manajemen acapkali ditemukan suatu alternatif solusi yang sangat mahal yang harus diambil untuk suatu hasil yang mempunyai nilai sangat tinggi.

5. Penentuan Pilihan Alternatif Solusi (Keputusan)

Penentuan pilihan solusi atau keputusan ini dalam tahapan pembuatan keputusan merupakan tahapan yang sangat kritis dan sangat menentukan. Pembuat keputusan atas dasar semua pilihan yang tersedia, dengan berbagai resiko, dampak dan peluang akhirnya harus sampai pada suatu titik pilihan keputusan. Pilihan ini harus diambil dengan kecermatan, kejelian, keberanian, tanggung jawab, dan komitmen yang besar. Tanpa sikap-sikap seperti itu suatu keputusan tidak akan mempunyai makna apa-apa. Sikap seperti inilah yang menciptakan berbagai dinamika dan perubahan dalam suatu organisasi.

b) Implementasi Keputusan

1. Legalisasi Keputusan 
Langkah ini diperlukan dalam suatu proses pembuatan keputusan sebagai suatu cara untuk memperoleh keabsahan dan komitmen serta dasar hokum dari suatu keputusan sehingga seluruh anggota, unsur-unsur pimpinan dan seluruh jajaran organisasi terikat untuk melaksanakan keputusan itu. Legalisasi ini diwujudkan berdasarkan ketentuan yang diberlakukan dalam suatu organisasi.

2. Plan of actions

Atas dasar keputusan formal organisasi yang secara hukum memperoleh kekuatan, maka rancangan oprasional atau plan of action dapat disusun. Plan of action mencakup hal-hal sebagai berikut:

a. Objective dan sasaran operasional

b. Penentuan tugas dan tanggung jawab bagi setiap, personel yang terlibat

c. Mekanisme organisasi dalam melaksanakan keputusan termasuk mekanisme pengawasan

d. Penentuan sumber-sumber daya yang diperlukan untuk setiap kegiatan, termasuk sumber dana

e. Time-line dari langkah awal hingga langkah review dan evaluasi

3. Sosialisasi dan Komunikasi

Langkah ini dipandang strategis untuk memasyarakatkan keputusan agar setiap orang memahami dalam rangka memenangkan dukungan untuk upaya yang mengandung pembaharuan. Tujuan yang perlu dicapai adalah support atau dukungan dari segenap anggota atau masyarakat organisasi terhadap upaya yang akan dilaksanakan. Sosialisasi dan komunikasi ini harus dirancang secara sistematik untuk menciptakan kondisi dan suasana yang favourable. Kritikan dan resistansi harus diantisipasi dan langkah-langkah penanggulangannya sudah harus disiapkan. Keseluruhan jalur komunikasi organisasi dan media teknologi yang diperlukan harus dimobilisir sedemikian rupa sehingga suasana yang favourable itu dapat diciptakan. Winning the support dari masyarakat begitu penting untuk ikut mendorong terwujudnya hasil yang diharapkan.

4. Action

Tahapan ini merupakan titik tumpu untuk keberhasilan tahapan implementasi keputusan. Tahapan action ini merupakan "putting thing into practice". Keseluruhan persiapan termasuk mekanisme organisasi yang telah disusun dicoba untuk bekerja melaksanakan keputusan yang telah diambil. Koordinasi, Komunikasi, dan kerja sama adalah kunci dari 
Page : 41-51

kelancaran proses implementasi ini Dalam pelaksanaan action ini ada beberapa hal yang kritis yaitu: organisasi, personnel, dan dana dalam suatu interaksi manajemen. Unsur kemampuan pimpinan untuk menggerakan rancangan adalah sangat penting. Pada awal action tentu akan ditemui berbagai kesulitan, pada langkah awal inilah diperlukan kesiapan seluruh aparat eksekutif untuk selalu siaga dalam menangani berbagai kesulitan yang muncul.

5. Pengawasan

Pengawasan adalah salah satu unsur yang dapat dimanfaatkan untuk membantu kelancaran implementasi. Pengawasan ini mencakup pemantauan atau monitoring, evaluasi dan intervensi untuk meluruskan apa yang ditemui tidak sesuai dengan ketentuan dan aturan yang telah ditentukan. Pengawasan ini dapat dilakukan oleh aparat yang ditunjuk untuk itu, atau langsung oleh unsur pimpinan kepada bawahannya.

6. Review dan evaluasi

Review adalah kaji ulang setiap langkah dan tahapan yang telah dilaksanakan sedangkan evaluasi adalah proses penilaian untuk mengetahui tingkat efisiensi dan efektivitas manajemen dalam rangka melaksanakan keputusan. Kegiatan ini tidak harus menunggu hingga keseluruhan langkah implementasi selesai, tapi dapat dilaksanakan secara terjadwal dan kontinue dalam rintangan waktu yang telah ditentukan. Dengan sistem review dan evaluasi seperti ini keseluruhan gambaran proses implementasi dapat di ketahui tingkat kemajuannya, kesulitannya dan hambatannya, karena itu langkah-langkah teknis untuk mengatasi semua persoalan dapat disusun secara sistemik dan sistematik.

\section{B. Komponen Pembuatan Keputusan}

Agar pengambilan keputusan dapat lebih terarah, maka perlu diketahui unsur-unsur / komponen-komponen dari pengambilan keputusan tersebut. Menurut Salusu (1996: 51) unsur-unsur / komponenkomponen dari pengambilan keputusan yaitu:

1. Tujuan dari pengambilan keputusan

2. Identifikasi alternatif-alternatif keputusan untuk memecahkan masalah. Setelah menetapkan tujuan, maka dapat dilanjutkan dengan menetapkan berbagai alternatif -alternatif yang mendasari mencapai tujuan tersebut. Untuk mencapai satu tujuan tentu ada banyak pilihan, namun tetap dipertimbangkan segala dampak dari alternatif yang diambil. 
Page : 41-51

3. Perhitungan mengenai faktor-faktor yang tidak dapat diketahui sebelumnya / diluar jangkauan manusia.

4. Sarana atau alat untuk mengevaluasi atau mengukur hasil dari suatu pengambilan keputusan.

\section{Peristiwa Tidak Terkendali}

Alternatif yang diambil harus mampu melihat pada kondisi sekarang terhadap kondisi yang akan datang, jangan sampai keputusan yang diambil tidak mempertimbangkannya. Dan keputusan yang sudah diambil jika karena diluar dari kemampuan kita menganalisisnya namun tetap terjadi maka harus diusahakan mencari solusi alternatif atas kondisi terbaru yang muncul.

Untuk sarana mengukur hasil harus ditetapkan alat atau sarana yang menjembatani antara keputusan terhadap realisasi. Jika keputusan yang dimbil tidak sesuai dengan realisasi berarti keputusan tersebut salah dan sebaliknya jika keputusan sesuai dengan realisasi yang dicapai maka dapat dikatakan keputusan tersebut berhasil.

\section{Metode Pengambilan Keputusan}

Cara mendekati analisis pengambilan keputusan sangatlah berpariasi. Menurut Brinckloe dalam Candra dan Rifa'I (2016: 163) ada empat metode pengambilan keputusan yang dianggap lazim dipergunakan dalam pengambilan keputusan organisasional diantaranya:

1. Metode rasional

Metode ini disebut juga model rasional. Ini adalah metode klasik yang secara implisit mencakup model birokratif dari pengambilan keputusan.

2. Metode tawar menawai inkremental (incremental-bargaining)

Hasil keputusan ini diperoleh sebagai jeripayah dan tawar-menawar yang melelahkan dan persuasif melalui perdebatan dan negosiasi.

3. Metode agregatif (Aggregative methods)

Metode ini mencakup antara lain tekhnik Delphi dan teknik-teknik pengembilan keputusan lainnya yang berkaitan. Seringkali metode ini memanfaatkan konsultan dan tim-tim staf dalam merumuskan kebijaksanaan-kebijaksanaan politik. Konsesus dan peran serta merupakan karakteristik pertama dari metode agregatif.

4. Metode keranjang sampah (the garbage-can) atau nondecision-making model Model ini dikembangkan oleh March dan Olsen. Model keranjang sampah menolak model rasional, bahkan rasional-inkremental yang 
Page : 41-51

sederhana seklaipun ia lebih tertarik pada karakter yang ditampilkan dalam pengambilan keputusan pada isu yang bermacam-macam dari peserta pengambilan keputusan, dan pada masalah-masalah yang timbul pada saat itu. Sering kali keputusan diambil tidak direncanakan sebagai akibat dari perdebatan dalam kelompok. Dalam membahas alternatif-alternatif, justru yang paling banyak diungkapkan ialah tujuan dan sasaran tetapi tidak mengevaluasi cara terbaik untuk mencapai tuuan dan sasaran itu. Pembahasan tentang pengambilan diwarnai oleh kepentingan pribadi, klik, persekutuan, konflik, pujian dan tuduhan, menggalang persahabatan baru, melepaskan ikatan lama, mencari kebenaran, dan menampilkan kekuasaan.

Kemudian supranto dalam Rifa'I (2020: 28) menjalaskan bahwa tahap keputusan manajemen memiliki unsur sebagai berikut:

1. Perlu adanya rumusan persoalan secara perinci.

2. Mengumpulkan data mengenai kenapa terdapat sebuah persoalan di organisasi, kemudian fokuskan kajian.

3. Berdasarkan informasi kemudian lakukan aktivitas tindakan lanjut untuk memberi solusi.

4. Mempersiapkan analisis pilihan atau yang disiapkan jika sebuah alternatif telah ditentukan.

5. Menentukan pilihan dari keputusan.

6. Tahap aksi, bahwa tanpa adanya aksi dari keputusan yang dibuat, maka hal itu sama saja dengan tidak mengambil keputusan dan organisasi juga akan mengalami stagnasi.

\section{KESIMPULAN}

Pembuatan keputusan mengenal berbagai prinsip dasar sehingga baik dalam tahapan perumusan maupun implementasinya pembuatan keputusan tersebut memenuhi syarat sebagai alat manajemen yang dapat memberikan panduan bagi anggota dalam bertindak dan berprilaku. Adapun PrinsipPrinsip tersebut antara lain : Keputusan pada dasarnya ditujukan untuk memecahkan masalah, karena itu setiap alternatif solusi hendaknya tepat untuk masalah yang dituju, setiap keputusan hendaknya merupakan alternatif terbaik dengan resiko yang amat minial, keputusan hendaknya sudah mempertimbangkan lingkup dan resiko secara sistematik dan sistemik, keputusan hendaknya tidak berada diluar zona of acceptance manusia, keputusan yang efektif adalah keputusan yang dapat dilaksanakan, keputusan hendaknya memecahkan masalah yang generik bukan masalah yang oprasional 
Ability : Journal of Education and Social Analysis

Volume 2, Issue 3, Juli 2021

Page : 41-51

teknis, kembuatan Keputusan terdiri dari tahap perumusan keputusan dan implementasi keputusan, pembuatan keputusan hendaknya menghasilkan suatu hasil yang dapat diukur serta keputusan tidak selalu harus dimulai dari data, tapi dari judgement.

\section{DAFTAR PUSTAKA}

Muhdi, dkk. 2017. Teknik Pengambilan Keputusan Dalam Menentukan Model Manajemen Pendidikan Menengah. Manajemen Pendidikan, Vol. 4, No. 2. Mustiningsih. 2014. Pembuatan Keputusan Dalam Kepemimpinan Pendidikan. Semarang: Fakultas Ilmu Pendidikan Universitas Negeri Malang.

Candra Wijaya dan Muhammad Rifai. 2016. Dasar-Dasar Manajemen. Medan: Perdana Publishing.

Imansyah, Yudi. 2017. Pengambilan Keputusan dalam Organisasi Lembaga Pendidikan. Pengambilan Keputusan, Vol.1, No.1.

Muhammad Rifa'i. 2020. Pengambilan Keputusan. Medan: Kencana

Salusu. 1996. Pengambilan Keputusan Stratrgik Untuk Organisasi Publik akan Organisasi Nonprofit. Jakarta: Profindo.

Suharman. 2005. Psikologi Kognitif. Edisi revisi Surabaya: Srikandi Ghalia 